\title{
Creativity of Dragutin Inkiostri as the Text of the Cultural Identity of the Balkans
}

\author{
Danijela Miodrag Dimković \\ Faculty of Philology and Arts, University of Kragujevac, Kragujevac, Serbia
}

\begin{abstract}
Citation: Dimković DM. Creativity of Dragutin Inkiostri as the Text of the Cultural Identity of the Balkans. SEE Archit Des. $2016 \mathrm{Mar}$ 02; 2016:10015. http://dx.doi.org/ 10.3889/seejad.2016.10015

Key words: colonialism; hybrid culture; imporialism; balkanism; orientalism; heritage; national identity; folk art.

"Correspondence: Danijela Miodrag Dimković. Faculty of

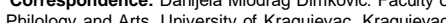
Philology and Arts, University of Krag

Recived: 02-Ja2010; Received: 02-Jan-2016; Revised: 14-Feb-2016

Copyright: ๑ 2016 Danijela Miodrag Dimković. This is an open-access article distributed under the terms of the Creative Commons Atrbution License, which permits medium, provided the original author and source are credited.

Competing Interests: The author have declared that no competing interests exist.
\end{abstract}

\begin{abstract}
AIM: This article is directly addressing to various aspects of the folklore heritage, postcolonial studies and their influence on the development of the national idea and creating a national culture that participates in the of cultural identity.

METHODS: Home premise is that some models of colonial discourse considered in the theoretical concept of postcolonial studies, are being reflective on the Balkans as well. The tradition which constitutes of culture and art, as well as a selection of different practices, meanings, gender, class and racial identification. Perceiving the intangible cultural heritage, folk culture as the context of social and cultural development of contemporary cultural policy, art production and development of the creative sector.

RESULTS: This kind of problematization seems necessary and appears as a form of reaction to the emergence of globalization, post-colonialism, imperialism, and similar forms of government which are based on various powe relations as an increasingly intense process of continually pose challenges to understanding and redefining their own heritage in the context of finding a national, cultural and Balkan identity.

CONCLUSION: In this context, creativity of Dragutin Inkiostri Medenjak (1866) during the late nineteenth and early twentieth century is being imposed as an appropriate choice for argument of the initial thesis.
\end{abstract}

\section{Introduction}

Postcolonial studies are related to the analysis of ideological discourse and discourse of power, the critique of modernism and Eurocentrism, primarily in subordinated and marginalized cultures or parts of the world. Referring to the postmodernist and poststructuralist theories and method of deconstruction, based on the colonial project they offer theoretical possibilities and concepts for interpreting contemporary cultural flows in the context of the old and the new hegemony and various forms of cultural resistance.

Modern analysis of culture is related to the study of post-colonialism with the aim of repositioning and the establishment of the re-analysis of cultural trends. Postcolonial theory is not and need not be exclusively related to the culture of Africa, Asia, South
America and Australia. It provides a theoretical framework and concepts for interpreting contemporary cultural flows and various forms of cultural resistance. Colonial discourse certainly has political effects on the part of the Balkans. We will try to make a connection with with the work of Dragutin Inkiostri and the basic theoretical postulates of the most famous representatives of postcolonial studies Edward Said (Benedict Anderson), Homi Baba and Gayatri Spivak.

This will be done in the context of the formation of cultural identity, positioning his creation, problematizing definition of power relations and political implications and consequences that directly affect the political and cultural reality of Serbia at the beginning of the twentieth century. We will also utilize the concept of Maria Todorova, which summarizes the initial theoretical reflection and changes certain political circumstances and scientific standpoint in relation to the formation of a Balkan identity. 
This article is directly addressing to various aspects of the folklore heritage, postcolonial studies and their influence on the development of the national idea and creating a national culture that participates in the of cultural identity.

\section{Balkan Identity through the Theories of Homi Baba, Edward Said and Gayatri Spivak}

The application of postcolonial theory to the question of the Balkans and Balkan identity seems legitimate when starting from the concept of scientific research of Homi Baba, because the subject of the analysis may be present in different spheres of the problem-specific and can be applied in any other context. Another reason that the Balkans is viewed through the colonial discourse is the connection of power and knowledge, which was being dealt by Michel Foucault in his analysis.

Exploitation of stereotypes for political purposes by Baba was used both in the Orient and on the Balkans, which is a common context of both areas. Based on that, Baba established the theory of colonial discourse over specification of stereotypes. Then nationalism is being interpreted as a dominant power in postcolonial discourse which tries to explain the nation in a variety of discourses. In the crossfertilization those discourses create classes, genders, ethnicity, and marginal group in order to show that historicism, Marxism and liberal democracy have not found a way to cope with the diversity of cultures and that it is necessary to alienate from the concepts and heritage resulting from this way of thinking [1]. Baba proposes the concept of the "third space" to allow the possibility to interpret "transnational" and "translational culture" [1]. Political refugees, on one hand, and territorial ambitions of global media technologies on the other hand, make culture become "transnational", whereby an unifying discourse of the nation, the people and the authentic folk tradition is not able to explain the anxiety of the global movement [1]. The third area mentioned by Baba establishes new structures of authority and political initiatives and that is a "hybrid space". All that the modernist mind could interpret as "underdeveloped", postcolonial discourse perceives as different and hybrid [2]. Hybridity is a metaphor that points to racial and ethnic mixing, or what is the cultural mix. This can be used in understanding the formation of the cultural identity of Serbia, which within the framework of the modernist discourse at the beginning of the twentieth century represented a pejorative meaning because it pointed out to an unwanted relationship with Ottoman culture and disturbing imaginary order of things, which presumed purity of cultural forms and shapes.
Within the architecture and applied arts in Serbia during XIX and XX century, the relationship between tradition and modernity is marked by extreme ideological complexity and different perspectives. One interpreted Europeanization and modernization through the return to the historical traditions of the Serbian people and the revival of native heritage. Other trends are linked to identification with international styles of western and central Europe. The social elite of that time sought to demonstrate modern and European character of Belgrade and Serbia in conjunction with political ideology. Starting from emigration of non Christian population during the nineteenth century to the planning and construction of the "European-style", the adoption of the European cultural tradition and highlighting the progress as the fundamental cultural values [3].

One of the most important theorists who analyzed problems of postcolonial studies is Edward Said, who made a huge impact with his book Orientalism and opened many discussions on the subject of the postcolonial theory. Said's discursive construction of the Orient exploits the notion of Orientalism comprised of forms, which shape visual and textual representation of one part of the world. Orientalism is not created in some fictional stories, but within a broad corpus of theory and practice developed in academic institutions, museums, colonial offices, anthropological and biological theories and analysis, creating a culture of discourse which operated in parallel with raw political and military reasons [4]. Knowledge and power create the image of other and the way the West perceives itself.

This approach indicates what is the distinctive trait of the postcolonial approach, which is that Said's analysis of knowledge and power in relations between the West and the East does not bring down to the proof of how the simple logic of force functions, or that there is something that could be seen as a conspiracy by the West to others, but it is a more complex approach, which assumes Orientalism or Eurocentrism as the dominant to the episteme of the West [4]. Orientalism in this sense can be understood as a speech on general or any "other". Postcolonial studies are also investigating the construction of Western discourse on which The Balkans is being constructed; specifically the general public is wellknown with the political structure of Serbia and the Serbs as primitive people. That was realized and still is realized in different media, theoretical, scientific, political and legal discourses, which are not real only in the West but also in the Serbian society itself. The system of values established on this way clearly demonstrates the desire of the social elite in Serbia in supporting and adopting the European cultural tradition and highlighting the progress as the fundamental cultural values at the beginning of the twentieth century. Inkiostri's artistic activity made him a contemporary, and an indirect participant in the 
events leading to the creation of the Serbian national art.

Inkiostri tried to revive his artistic ideas while remaining consistent to his ideas on reviving the tradition of folk creativity in the period when the Serbian art was increasingly moving away from national settings and turned by impacts of the global flows. Equally important discourse of the national authenticity is folk culture and ethnicity. In view of these criteria of nationhood, as an assumption of the common culture that emerges as the difference in comparison with others, Inkiostri was developing his ideas about the unique and authentic Serbian style.

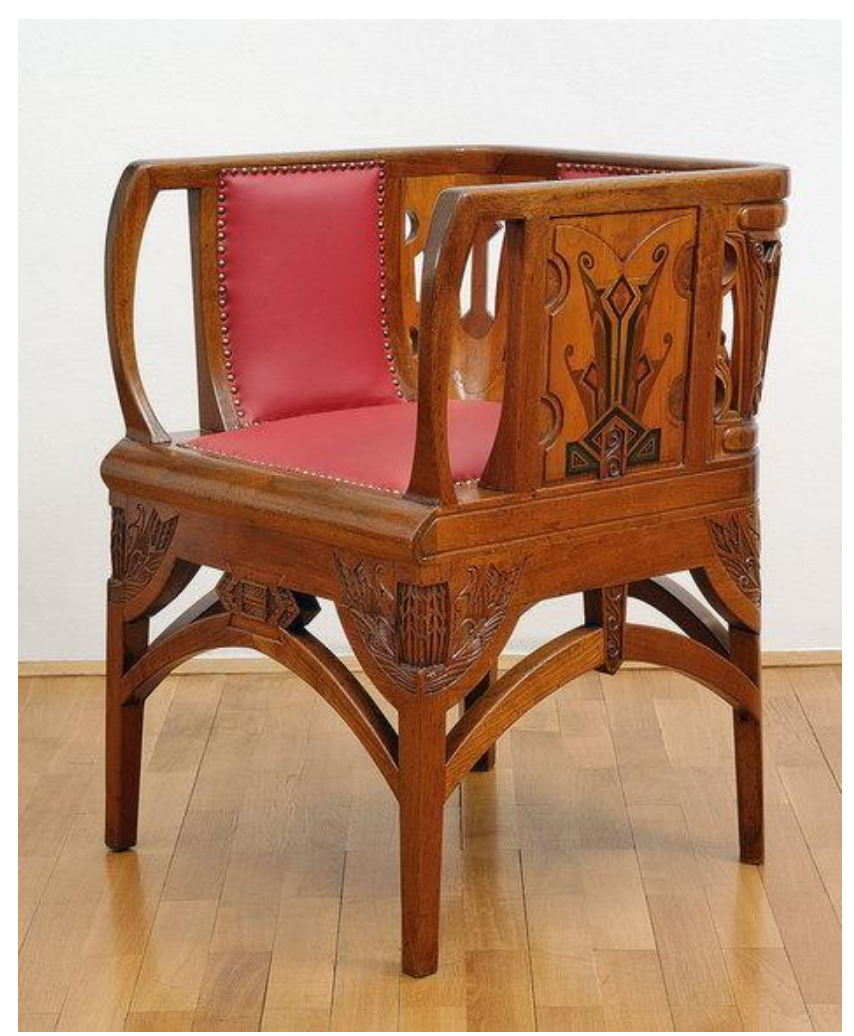

Figure 1: Dragutin Inkiostri Medenjak, armchairs made according to Serbian traditional folk art motifs

The ethnographic heritage is systematized and interpreted as the "national treasure". At that time folklorism although treated as a minor segment of architecture and art was an important component in building a modern national and cultural identity. Such folk culture has survived as a powerful symbol of cultural unity, which allows maintaining national cohesion between different ethnic groups, cultures and nations that aspire to the same premises and territories. In fact, it was possible to demonstrate the conception of cultural identity as well as the idea of national character through architecture and its decorative arts. Folklore heritage, as an authentic remain of the nation's history could have been interpreted as an extension of national culture, which was not "corrupted" by other "foreign" elements. Such overview of Inkiostri's approach to the formation of cultural identity of one nation, only now can be viewed in a new and different way through the framework of postcolonial studies and the concept of hybridity.

The concept of hybridity becomes crucial, because it considers the reality of migration around the world, meeting and overlap of races, ethnicities and cultures in a global multicultural world.

Culture and Imperialism are one of the key examples in cultural studies. Said put his analysis into a function of a comprehensive examination of the relationship between the imperial ventures of the past and the present and culture, which strengthened and gave new impulse to the analytical postcolonial studies [1]. By the time postcolonial studies appeared the era of anti-colonial struggle and the creation of nation-states of the Third World was completed, block division disappeared, and the disintegration of the national states begun. The very concept of the nation was now being seen as intrinsically destructive, essentially authoritarian political order and cultural guidance. According to that, Gayatri Spivak claims that nationalism is reversed or inverted legitimacy of colonialism, with regard to nationalism as repeating "epistemic violence" of the colonialism it rejects. National states, created in the post-colonial period around the globe, postcolonial theory sees as the extended arm of Western hegemony, not only as a political product of the former imperial powers, but as a product impregnated by concepts, divisions and values borrowed from the Western modernity [5]. We can perceive Serbia as marked by this concept, at the beginning of the twentieth century, trying to be established as part of the contemporary European context, with strict alienation from the Ottoman culture and heritage, which are classified under the folkloric heritage as ineligible for inclusion in contemporary modern trends.

\section{The Nation, Conceived Community}

In his book - "The nation, conceived community" Benedict Anderson encourages analysis of nationalism as a narration. According to Benedict, every nation constructs its identity based on structures built from symbols and rituals related to the territorial and administrative categories. Anderson wants to show how the last two centuries of imagining the nation relied on cultural heritage, loyalty and universal human need to provide continuity and the general structure through some instances for their own transience and short-living [6]. Anderson's analysis played a significant role in the framework of postcolonial theory and the study of nationalism, in which each story of unity or identity is networked into 
imperialism. Another specificity of postcolonial studies is striving to detect voices of the unheard majority, the lower marginal layers and groups.

Relying on the Gramsci's theory of hegemony we can talk about opposition to the social elite and those who are on the margins of history, exploited, subordinated and silent social groups who lack class and cultural awareness. Based on this theory of Gramsci shows that the ruling class does not govern simply by means of force, but it must have some measure of acceptability in the classes in which governs, which is mainly achieved on the basis of moral and intellectual leadership. The relationship between opposing classes is deeply dependent on the cultural and ideological relations that are established between them. This is not about domination but about the struggle for hegemony which includes the moral, cultural, intellectual, and therefore the political leadership of the entire society [7].

In addition to the state funded high profile undertakings, Inkiostri was continuously publishing articles and presenting his theory of national style and the possibilities for its application. At the end of 1907 he printed his book "Rebirth of the Serbian art" in Kolarac's edition. The book "Rebirth of the Serbian art" and the brochures "Our architecture" and "New Serbian style" where Inkiostri criticizes our architects to neglect the local climate and tradition, as well as European interest in folk art, finds a strong condemnation of renowned architects of that period who also belonged to the ruling national, ideological and social class at the beginning of the twentieth century [8]. Architect Branko Tanazević was one of the biggest opponents of Inkiostri's work, declaring that Inkiostri's published works are incomprehensible in general; incorrect in details and that Inkiostri does not have enough vocational education for such a project. It is obvious that for these reasons that Tanazević quoted, Inkiostri was not accepted fully by the "ruling ideology", as well as his work and dedication to the study and implementation of national creativity. However, as the concept of hegemony is not a dominance but adapting to oppositional class cultures and values, allowing them to be expressed in their own space Inkiostri was summoned to decorate the Serbian pavilion at the World Expo in Turin (1911), with the approval of the Ministry of National Economy for the decoration of the salon, where he worked under the supervision of Branko Tanazević. Freedom in his ideas and his approach was completely denied by Tanazević because he did not allow him to apply national ornaments. The concept of hegemony demonstrates that the bourgeoisie does not want to destroy the culture of the working class, but to "articulate" it according to the requirements of their own culture and ideology so that in the process the politics and culture of the working class is being changed as well. So the relationship of Dragutin Inkiostri and his work can be seen as by continuous "negotiation" with the ruling class on the cultural and ideological level. "Methodological criterion on which rests our study must be based on the following: the supremacy of one social group is expressed in two ways - as "domination" and as "intellectual and moral leadership". One social group dominates to antagonistic groups trying to "liquidate" or subordinate. One social group can, actually must to previously establish the "leading role" in order to gain power ... [7].

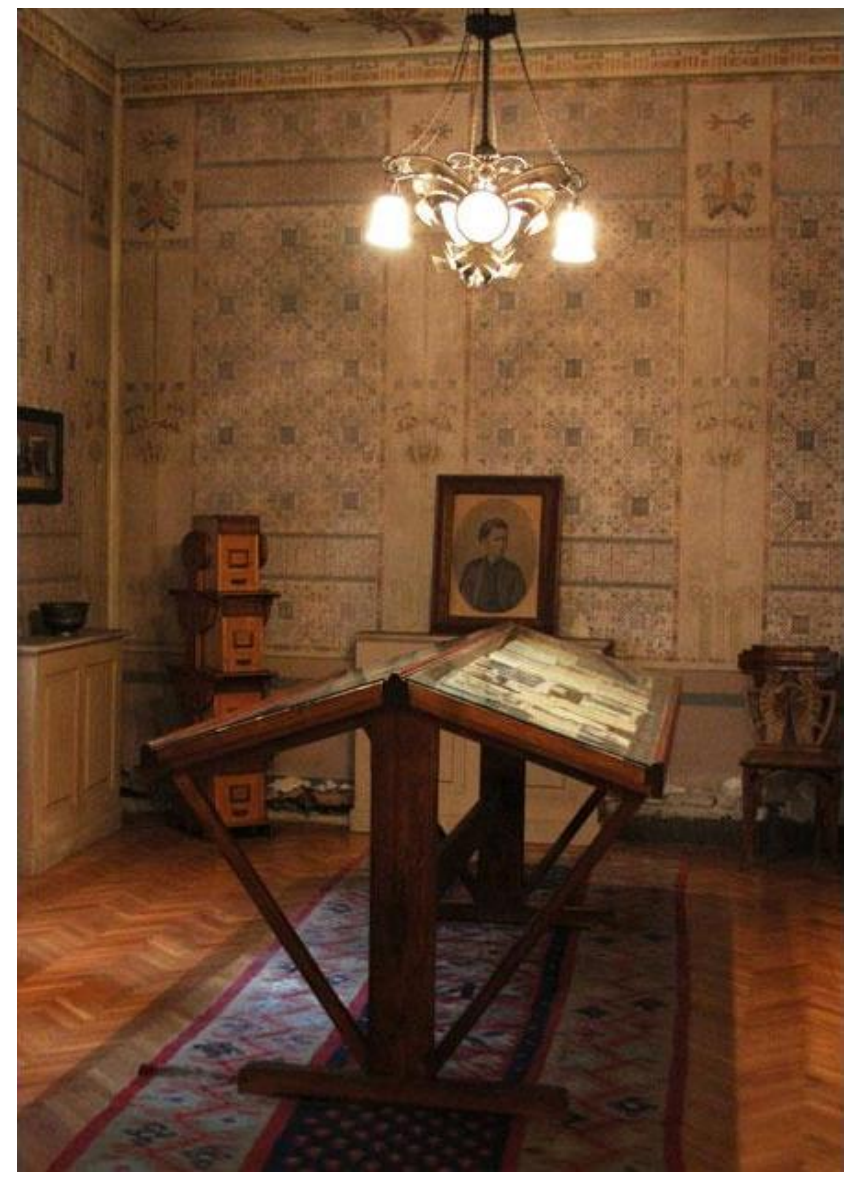

Figure 2: Dragutin Inkiostri, The interior of the house Jovan Cvijic, Serbian scientist and geographer.

Change of social relations during the historical period of Serbia at the beginning of the twentieth century refers to the struggle over the form of cultures, traditions and ways of life of the national classes. One of the main forms of resistance to the reformation of the people was the folklore tradition. For this reason, the later popular culture is often associated with questions of tradition, traditional forms of life and is seen as the product of conservatism and turning towards the past. Dragutin Inkiostri comes to know the views and tendencies of this misconception already in his early period of creativity. In this period of modernization, "Cultural change" is a process where some cultural forms are evicted from the center of national life and being marginalized. Then they resort to radical and active removal of such forms so that 
something else takes their place and everything is presented as a necessity for reform. "In one way or another "people" is often the subject of "reform": often for its own good, of course - "the best interests". The transformation is certainly necessary in the process of reviewing and active work on existing traditions and activities, their active processing into something different. It seems that Dragutin Inkiostri understood the issues of relations between the traditional and its transformation into a contemporary context at the beginning of the twentieth century. Although he apparently tried to present the traditional values as prime, different tendencies prevailed in search for a new European and global identity and development and also as a deviation from the Ottoman tradition and its centuries-long influence.

International exhibitions also contributed to the affirmation of the folk art. The first internationa exhibition Inkiostri participated in was held in 1906 in Brussels, dedicated to the decorative arts, titled "Art in the house". Exhibitions were complex events that combined commercial and industrial fairs, carnivals, music festivals political spectacles museum exhibitions and art galleries. Material culture of the exotic colonies was exhibited simultaneously with the latest technical developments. Progressivity in the cultural, artistic, scientific, industrial, commercial matters; in transportation, technology, represented a crucial ideology and the idea that the world is evolving from primitive forms to the higher ones. In other words, it was a manifestation of the power of Europe over the colonized peoples and legalization of the colonial policies of powerful nations.

\section{Balkanization of Maria Todorova}

In the preface to the second edition of the book "Imaginary Balkan" in the Serbian language, Maria Todorova presents certain disagreement with the opinion of some theorists about the location of the Balkans as the subject of postcolonial studies. She argues two aspects and conclusions implemented through distinctions Orient - Balkans. The first difference Todorova names is that the Balkans is geographically and historically specific, while the Orient is what is revealed when traveling and has a metaphorical and symbolic nature. It is through metaphorical manifestations how Todorova establishes a connection to the Orient and the Balkans, which after the collapse of the Ottoman Empire increasingly became a symbol for something aggressive, intolerant, barbaric, halfway-developed, semi - civilized, semi-oriental [9]. Balkanism is described as a pejorative discursive construction that forms a decisive role to deal with the Balkans. Balkanism and Orientalism are conceptually different in perception from the perspective of the West. Orient represents the exotic and imaginary place to escape to from urbanized areas, a symbol of wealth, sensuality and desire, the Balkans is devoid of mystery and exoticism due to the absence of wealth and former current affairs of themes of freedom [9]. Another aspect of not fitting the Balkans into postcolonial discourse by Todorova is that she does not perceive Balkans as the Ottoman colonial empire and indicates there is a lack of institutional and legal differences between the conquerors and the conquered territory and that the Ottoman conquest did not imply the introduction of civilizing mission.

This region carries two heritages; one is Byzantine, and the other Ottoman. And this second one, the Ottoman legacy is the onset of the Balkans as we know it. The Balkans is a boundary in the eyes of the West. In contrast to the West, Orient has always stood firmly as a well rounded whole, as a counterpoint; the Balkans was something in between, bridge and intersection. The Balkans is semi-colonial, semi-civilized and semi-oriental in this discourse. Todorova finds roots of this notion of the Balkans in one specific Eurocentrism that accepts only that part of it which is based on Western culture as Europe. As it's geographically inseparable from Europe, the Balkans is culturally constructed as "internal otherness", ministered to absorb a multitude of external political, ideological and cultural frustrations stemming from tensions and contradictions inherent in the regions and societies outside the Balkans. In time, Balkanism became a substitute for the emotional relief previously provided by orientalism, having freed the West from charges of racism, colonialism, Eurocentrism and Christian intolerance towards Islam.

The beginning of the twentieth century is a period of discovery and construction of the Balkans as a new one. How Todorova observes that, this unique region is situated in existing molds that facilitate views of the world and its understanding. One of the biggest problems of the Balkans was its ethnic diversity. In fact, the nation-state must be ethnically homogeneous, while the ethnic minority presents a problem in the process of state formation, as seen by the west. Scientists inclined to Balkans do not see it as a primitive part of the world, but as a region full of inexhaustible but underdeveloped resources, and the Balkans as the Ethnographic Museum of Europe, the Balkans for them was and remains intermediate stage between savagery and civilization.

\section{Dragutin Inkiostri as the Text of the Cultural Identity of the Balkans}

The interest in folk culture in artistic and intellectual circles, not only in Serbia, but in Europe reinforces in the late eighteenth and early nineteenth 
century, precisely at a time when popular culture began to fade under the influence of technological and urban development. The unity of the folk culture was emphasized in the context of a nation that is at the same time failed to recognize the social stratification, nor have understood the historical processes of change within popular culture. In such circumstances, the traditional culture is an instrument of ideological mobilization and national homogenization and in this context incorporates the content of the cultural policies of the late nineteenth and early twentieth century. From the standpoint of policy, its objectives, priorities and instruments of the European countries folk culture has found itself on the margins of things at the beginning of the twentieth century. Reasons for this are very complex and can be found in the context of the relationship towards folk culture, as well as the negative consequences of strengthening national ideology during the first half of the twentieth century, which resulted in armed conflicts of the First and the Second World War. Following, devalorisative narration of the Balkans taken over by its inhabitants and mostly national elites of the Balkan countries, which often give themselves a task to "de-balkanise" their nations. Such rejection of the Balkans was already outlined in the early twentieth century. Serbian political elite, aiming at termination of Balkan heritage, because it actually imposed oriental, Ottoman and Muslim heritage to the Serbian people and pointed out to the need for reaffirmation of an old authentic European and Christian identity of the Serbs. The Croatian political elite demanded a break with the Balkan and oriental tradition, except they determined it as an Orthodox- Byzantine heritage. The phenomena of "national culture" are much more complex than it was shown in the ethnological research from historical point of view. In addition it is very important that the culture of the individual layers interferes with each other. Cultural phenomena do not exceed only from region to region but also from the upper classes in the lower layers, and vice versa, and in doing so, it is very important to point out, all these phenomena are constantly changing and adapting to different layers, time and "appropriate opportunities".

This sequence of historical events can be viewed as another reason why the work of Dragutin Inkiostri had no direct successors. Before the advent of Inkiostri, folk art was considered only from the ethnographic point of view in Serbian culture. Through his works, folk ornament has become a permanent element of applied art and industrial production. Already in the period between the two world wars, many pieces of furniture, the ceramics, fabrics and textures appeared with motives taken from folk art. However, this method of using national ornaments was the exact opposite to Inkiostri's theoretical concepts and his works [10]. Elements of folk art were used without any organic connection of form and ornamentation, as just one of amongst other decorative motifs. Course of the national and cultural emancipation of modern Serbia and the process of constructing Serbian national identity is constantly supported by complex ideological system based on cultural representation. One of the aspects of this time is certainly the art in its broadest meaning.

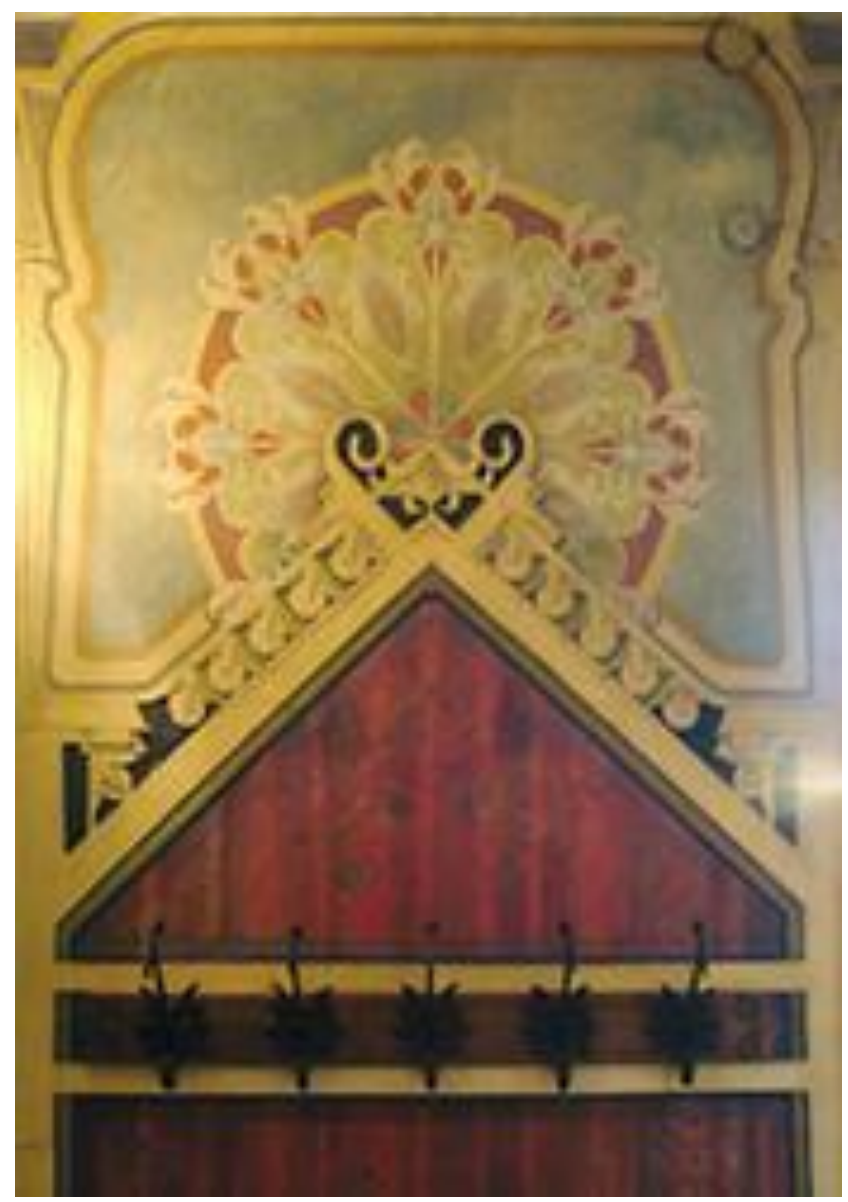

Figure 3: Dragutin Inkiostri, Interior detail of the house of Jovan Cvijic

If art and culture are not seen as a closed system of shapes as indicated by the established interpretive tradition, but approached to from different contexts: the Marxist theory of culture, critical theory of the culture industry, hegemony theory, philosophy of everyday life, structuralism, text theory, postcolonial theory, numerous conclusions about the nature of identity it can represent, can be reached. Art as a form of production is determined by political interpretation of artistic solutions as signifying anticipation social (geographical, racial, gender, ethnic, class, everyday) identity. By perceiving the art of Dragutin Inkiostri it observes the fact that his decorative narration offers a huge oeuvre of visual historical data. An entire world of the past appears as the text of indigenous heritage, which is being introduced into a policy of articulation and production of identity that is based on the continuous shaping of everyday life. Since no discipline is self-sufficient for reading and analysis, not a single creation can be viewed through a set of defined rules, biographical preaching, stylistic, 
morphological or formal analysis, because it conceals politics and ideology in such a manner. Extensive creativity of applied artists during the nineteenth and the twentieth century requires consideration beyond the stylistic and theoretical focus of classical and romantic ideals. Art and culture can't be subordinated to "exact" evidence that rejects everything that does not fit into the order, because it can be about non artistic ideological content. It is necessary to avoid blurring of the power of economy which would make impossible to deal with the past. Given that neither any critical contemplation must be constructive in terms of its contribution to new insights there is a need for a new re-reading of Inkiostri's creativity and artists who advocated for the implementation of the folklore heritage with us. The quest for national and cultural identity and the constant need to fit into broader civilizational frameworks, which simultaneously problematize it, represents only one aspect of the process of identity construction. As the political boundaries do not coincide with ethnic, search for national identity is a very complex search with us.

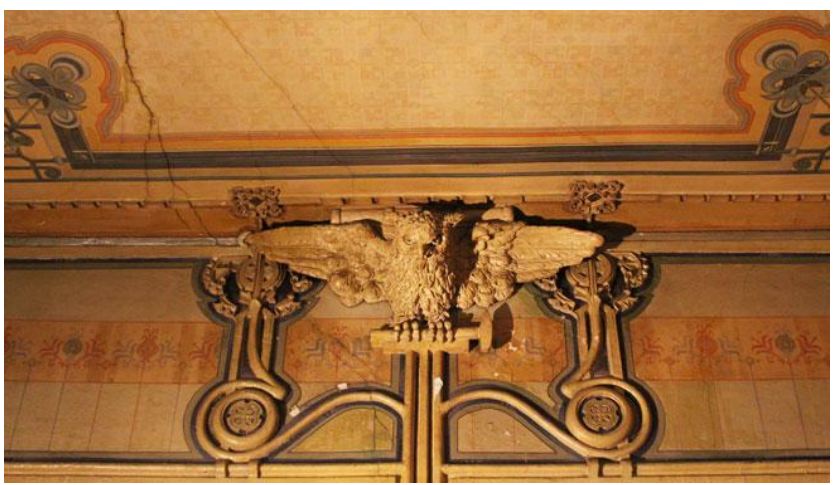

Figure 4: Dragutin Inkiostri, Interior detail of the house of Jovan Cvijic, walls and ceilings painted in al secco technique and the plastic decoration was made by motifs of flora and fauna

In conclusion, even now, at the beginning of the twenty first century, a large number of research of the "folk culture" in Europe appears as a tendency of conservation, rediscovering and developing heritage as the most important basis for the development of the identity of a state, the people of the region, communities, ethnic groups. Explicitly emphasize the preservation of cultural diversity as one of the main goals of Eurointegration processes. All researches of the phenomena associated with folk creations made in Europe, agree that without popular culture there is no culture at all, especially in the context of the origin and grounds of the general ethical and aesthetic value system. Culture based on tradition and historical dimensions must be understood from the inside, by its own logic. Culturally subject is more complex than what ethnological researches show; development would be related to attitudes committed to premise that folk art and culture should become part of modern life and culture of the people, this is why is necessary to channel and encourage modernization, hybridization and modernization of creativity and its placements. An integral part of the cultural policy should certainly be the development concept, and the efforts of regional and local communities to enable folklore to be commercially profitable [11]. Of course, there is the question of maintenance and development of culture in the contemporary context where traditional folk arts, culture and crafts are part of everyday life of the population. This clearly indicates the need to actively work on promoting and reading the folk tradition in a completely new way. As to this issue speaks Nestor Garcia Canclini in his essay "The hybrid culture, hidden power" which describes the relationship of modern and traditional culture and the way in which the postmodern global culture complicates the traditional accepted forms and ways of expression and behavior. He tends to show that it is impossible to talk about the homogenization of global culture of the postmodern world, but rather the reconfiguration of traditional cultural forms under the influence of new processes. New world creates a new public sphere and new cultural spaces, which are impossible to understand if we apply the strict division between the old and new, traditional - modern, ours and theirs, East and West, but it came to hybridization of these binary oppositions influenced by many factors from technological revolution to demographic changes [12].

Regardless of how the problem of multiculturalism was dismissed by the state-legal basis and what political and ideological resistance may cause the influence of writers, intellectuals, religious beliefs, food, fashion, music or art migrants from all over the world interferes with the dominant culture of the West, creating hybrid forms of culture [1]. Internal hybridity of the most of the modern societies will be established in interaction of economic spheres of interest, class inequalities and the action of various forces of hegemony which cast a completely new light and a new assessment of the formerly established relations between the West and others.

\section{References}

1. Đorđević J. Postkolonijalna teorija diskursa. Univerzitet u Beogradu, Fakultet političkih nauka, 2008.

2. Baba H. Smeštanje culture. Beogradski krug: Beograd, 2004.

3. Ignjatović A. Jugoslovenstvo u arhitekturi 1904-1941. Beograd, 2012.

4. Said E. Orijentalizam. XX vek, Beograd, 2000.

5. Spivak GČ. Kritika postkolonijalnog uma. Beogradski krug, Beograd, 2003.

6. Anderson B. Nacija: zamišljena zajednica. Plato, Beograd, 1998.

7. Gramši A. Hegemonija, intelektualci i država. Studije kulturezbornik, ed. Jelena Đorđević, Službeni glasnik, Beograd, 2008.

8. Vulešević S. Dragutin Inkiostri Medenjak - pionir jugoslovenskog dizajna, Beograd, 1998. 
9. Todorova M. Imaginarni Balkan. Naklada Ljevak, 2015.

10. Inkiostri DM. Preporođaj Srpske umetnosti, Beograd, 1907.

11. Đurković M, Vujadinović D. Narodna kultura u kulturnoj politici Srbije, Balkankult, Beograd, 2011.

12. Kanklini NG. Hibridne kulture, prikrivena moć. Studije kulturezbornik, ed. Jelena Đorđević, Službeni glasnik, Beograd, 2008. 